\title{
Using the Fiber Preparations in Meat Processing
}

\author{
Ivan Fiodorovich Gorlov ${ }^{1,2}$, Tatiana Mikhailovna Giro ${ }^{3}$, Vadim Valentinovich Pryanishnikov ${ }^{3}$, Marina Ivanovna \\ Slozhenkina ${ }^{1,2}$, Aleksandr Vasilievich Randelin ${ }^{1}$, Natali Ivanovna Mosolova ${ }^{1}$, Elena Yurievna Zlobina ${ }^{1}$ \& \\ Andrey Vladimirovich Kulikovskiy ${ }^{1}$ \\ ${ }^{1}$ Volga region research institute of manufacture and processing of meat-and-milk production, Volgograd, Russia \\ ${ }^{2}$ Volgograd State Technical University, Volgograd, Russia \\ ${ }^{3}$ Saratov State Agrarian University Named After N. I. Vavilov, Saratov, Russia \\ Correspondence: Ivan F. Gorlov, The Volga region research institute of manufacture and processing of \\ meat-and-milk production, 400131 Volgograd, Russia. Tel: 7-844-239-1101. Fax: 7-844-239-1142. E-mail: \\ niimmp@mail.ru
}

Received: July 1, 2015

doi:10.5539/mas.v9n10p54
Accepted: March 27, 2015

Online Published: August 30, 2015

URL: http://dx.doi.org/10.5539/mas.v9n10p54

\begin{abstract}
Due to the growing segment of dietary fiber preparations on the World market and to the need to expand the range of food products within the Scientific Concepts of Functional Foods in Europe, the authors studied the properties of the roughage, developed the ways of their dispensing use in food products with the required and improved characteristics to be ensured. The studies identified the chemical composition, the safety characteristics, the functional and technological properties, and the microstructure of the wheat fiber products of the series "Vitacel" (produced by «J. Rettenmaier \& SohneGmbH», Germany). The microstructural analysis helped to prove the capillary-fiber structure of the fiber "Vitacel", which provides high water retention. The fact that the food fiber preparations have significant sorption capacity and a high degree of swelling has been experimentally proved. The rational doses and the hydration conditions in the meat systems have been substantiated. Based on the research results, we can conclude that the fiber of the series "Vitacel" has a number of positive functional and technological properties that allows recommending it for all kinds of meat, fish, and confectionery products.
\end{abstract}

Keywords: dietary fiber, functional foods, health, meat, properties, quality

\section{Introduction}

According to the modern theory of nutrition, the daily human diet should contain all of the specified set of nutrients in the required amount and ratio, as well as the dietary fiber. The role of the latter in the diet increases, due to the versatility of known functions in the body (Dahm et al., 2010; Eshak et al., 2010; Pogozheva et al., 2010; Viuda-Martos et al., 2010; Cui, Nie, \& Roberts, 2011; Dülger \& Şahan, 2011; Cho \& Almeida, 2012). Therefore, targeted enrichment of the mass consumer demand products with dietary fibers has become widespread in industrial production (Ramirez-Santiago et al., 2010; Kamaljit, Amarjeet, \& Tarvinder, 2011; Bchir, Rabetafika, Paquot, \& Blecker, 2014). Currently, the fiber preparations have become popular and are used by enterprises of the food industry due to their high functional and technological health properties, as well as to the economic indicators (Leão, Melo, Franca, \& Oliveira, 2013; Yangilar, 2013; McGill, Fulgoni III, \& Devareddy, 2015).

The modern diet has a relatively low content of dietary fiber - the total consumption of fiber and pectin is less than 10 grams per day, which is almost three times lower than the optimal amount (European Food Safety Authority (EFSA), 2010).

Foods rich in dietary fiber usually require a more thorough mastication. In the human stomach, fiber binds water that makes the meal nourishing in the presence of little energy value of the fibers. The roughage promotes binding and excretion of bile acids, neutral steroids, including cholesterol, reduces the absorption of cholesterol and fats in the intestine. It slows the synthesis of cholesterol, lipoprotein, and fatty acids in the liver, promotes the synthesis of the enzyme, which causes the fat degradation, i.e. has a positive effect on lipid metabolism (Kendall, Esfahani, \& Jenkins, 2010; Hong, Zi-jun, Jian, Ying-jie, \& Fang, 2012). 
Recently, the fiber extracted from wheat, soybean, carrots, beets and different fruits have been widely used in functional food products (O'Shea, Arendt, \& Gallagher, 2012; Kohajdová, Karovičová, \& Jurasová, 2013). These preparations are also used in meat products to improve water binding capacity and to increase the output of finished product (Grossi, Søltoft-Jensen, Knudsen, Christensen, \& Orlien, 2011; Sánchez-Zapata, Díaz-Vela, Pérez-Chabela, Pérez-Alvarez, \& Fernández-López, 2013; Mehta, Ahlawat, Sharma, \& Dabur, 2015). Thus, fiber being not a food supplement is of great interest not only in terms of technology, but also very necessary in the implementation of the Scientific Concepts of Functional Foods (Van Der Kamp, Jones, McCleary, \& Topping, 2010; Elleuch et al., 2011; Dhingra, Michael, Rajput, \& Patil, 2012; Jones, 2013).

\section{Method}

The objects of the study were: the basic raw material (top grade beef, semifat pork meat); preparations of wheat fiber «Vitacel» (WF 200, WF 400, WF 600), manufacturer «J. Rettenmaier \& SohneGmbH», Germany; meat products made according to the formulations developed.

The mass fraction of moisture was conducted in accordance with the requirements of Government Standard of Russian Federation (GOST) 9793-74. The mass fraction of fat was determined by the Soxhlet method according to GOST 23042-86. The mass fraction of total ash was determined to GOST 31727-2012 (ISO 936:1998). The mass fraction of protein was tested photometrically and by the Kjeldahl method in accordance with GOST 25011-81 with pre-mineralization of the samples. The $\mathrm{pH}$ was determined by potentiometry; the amino acid composition - by the ion-exchange chromatography on the amino analyzer AAA- 881 . The fractional composition of proteins was determined by the successive extraction of the protein fractions by the suitable solvents and the time-series identification of the protein according to the biuret reaction. The histomorphological studies were carried out according to GOST 19496-2013. The functional and technological properties: the water binding capacity (WBC), i.e. the ability of an ingredient to contribute to the gel formation or firmness, when water has been added, was determined by the method of Tuominen and Honkavaara (1982); the water holding capacity (WHC) of model forcemeat systems was determined by the Grau and Hamm method (Grau, R. \& Hamm, R., 1957); the structural and mechanical properties were tested according to the recommendations by Antipova, Glotova, and Rogov (2001); the organoleptic characteristics were tested according to International Standard 8589 (International Organization for Standardization (ISO), 2010) and in accordance with the requirements of GOST 9959-91. The presence and the stability of the test smell were evaluated by an instrumental method on a special unit "electronic nose" (Korenman \& Kuchmenko, 2002); the color characteristics were measured on the colorimetric system "CIE L*a*b*" and "CIE XYZ" according to the reflection spectra on the spectrophotometer SF-18 (Antipova, Glotova, Titov, \& Panov, 2002); the swelling capacity investigation of the preparations of the series "Vitacel" was conducted in accordance with the instructions by Stromberg and Semchenko (2001).

\section{Results and Discussion}

The physiological and technological effects of the dietary fiber preparations depend on the solubility, and therefore on the structural features, the forms ratio, the degradation degree. In this regard the authors clarified some of the indicators of the dietary fiber preparations of the series "Vitacel" (Table 1).

Table 1. Composition and properties of the vegetable fiber preparations

\begin{tabular}{llll}
\hline \multicolumn{1}{c}{ Indices } & WF-200 & WF-400 & WF-600 \\
\hline Content of the dietary fiber in dry matter, min.\%97 & 97 & 97 \\
Moisture, max.\% & 8 & 8 & 8 \\
Ash, max.\% & 3 & 3 & 3 \\
Protein, \% & $0.40 \pm 0.06$ & $0.40 \pm 0.06$ & $0.40 \pm 0.06$ \\
Fat, $\%$ & $0.20 \pm 0.02$ & $0.20 \pm 0.02$ & $0.20 \pm 0.02$ \\
pH & $6.5 \pm 1.5$ & $6.5 \pm 1.5$ & $6.5 \pm 1.5$ \\
Phytic acid & abs./none & abs./none & abs./none \\
Gluten & abs./none & abs./none & abs./none \\
Average fibre length, $\mu \mathrm{m}$ & 250 & 500 & 80 \\
Average fibre thickness, $\mu \mathrm{m}$ & 25 & 25 & 20 \\
(according to figures from the manufacturer) & & & \\
$\begin{array}{l}\text { Grinding fineness, } \mu \mathrm{m} \\
\text { (according to figures from the manufacturer) }\end{array}$ & $90 \%<12090 \%<30090 \%<70$ \\
\hline
\end{tabular}


The quality and the yield of the products largely determines the level of hydrophilicity and water retention, which are closely related to the macro- and microstructure of the substances.

The microstructural studies of the wheat fiber have shown that it has a capillary-fiber structure of different lengths and thicknesses and is represented by strong fibers oriented in different directions that provides holding water by ionizable functional groups not only externally but also internally (Figure 1).

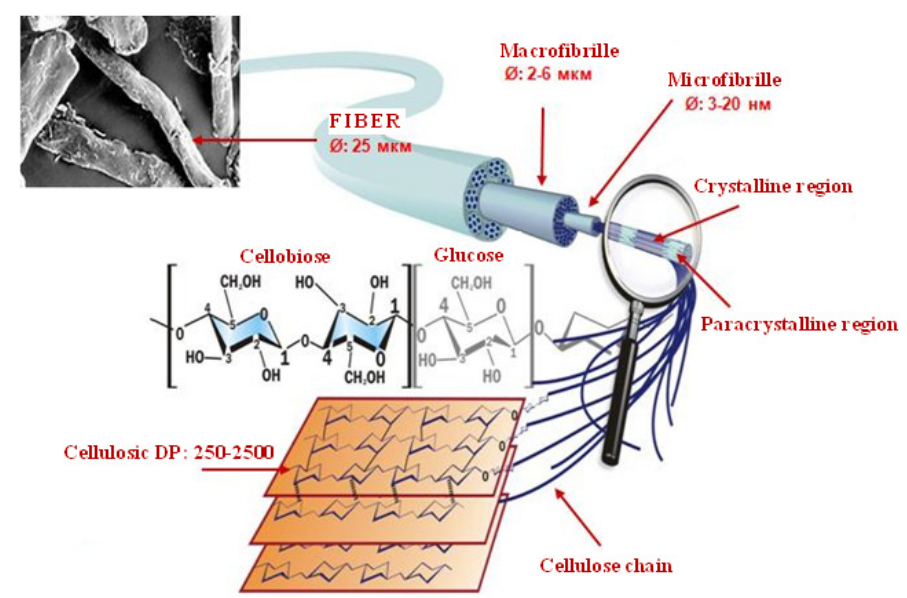

Figure 1. The microstructure of the fiber

The microstructural characteristics of the plant fiber of the series "Vitacel" are shown in Figure 2 by the example of WF-200.

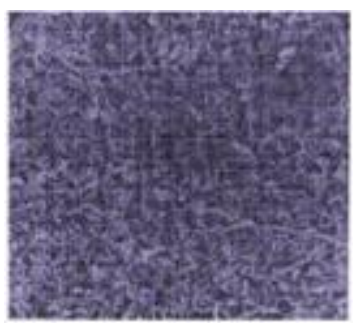

A)

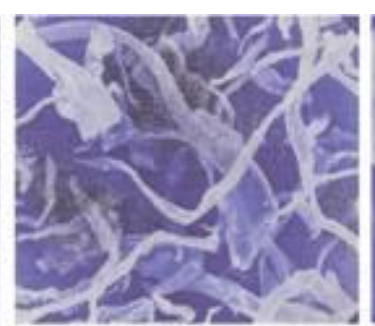

B)

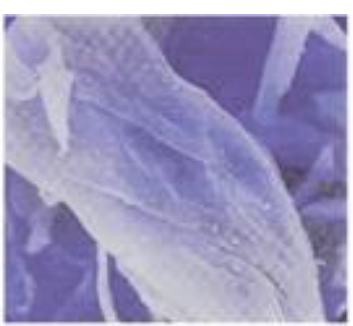

C)

Figure 2. The microstructural characteristics of the preparations of the series «Vitacel» WF-200. (A) 40x magnification, (B) 400x magnification, (C) 1000x magnification

It has been experimentally established the preparations of the series "Vitacel" to contain $24-27 \%$ hemicellulose in their composition. Cellulose was analyzed in the residue after separation of hemicelluloses. The method is based on the cellulose ability to hydrolyze on boiling with concentrated sulfuric acid to form monosaccharides. Lignin comprises a variety of functional groups: aldehyde, carboxy, phenolic, alcoholic, some of which are methoxylated. The dietary fiber contains lignin of $0.5-2.0 \%$.

The investigation of the fractional composition of the dietary fiber showed that depending on the kind of preparations, they contain insoluble forms of $35-95 \%$, and the rest of them is soluble roughage. The average chemical composition of the wheat dietary fiber of the series "Vitacel" is presented in Table 2.

Table 2. The chemical composition of the dietary fiber wheat preparations of the series «Vitacel»

\begin{tabular}{lccc}
\hline \multicolumn{1}{c}{ Constituents of the food fiber } & WF-200 & WF-400 & WF-600 \\
\hline Total value of the food fiber, \% & $96.0 \pm 2.0$ & $96.0 \pm 2.0$ & $96.0 \pm 2.0$ \\
included: cellulose, \% & $72.0 \pm 2.0$ & $72.0 \pm 2.0$ & $72.0 \pm 2.0$ \\
hemicellulose, \% & $25.5 \pm 1.5$ & $25.5 \pm 1.5$ & $25.5 \pm 1.5$ \\
lignin, \% & $0.5 \pm 0.1$ & $0.5 \pm 0.1$ & $0.5 \pm 0.1$ \\
\hline
\end{tabular}

The microbiological indices are given in Table 3. 
Table 3. The microbiological status of the preparations of the series "Vitacel"

\begin{tabular}{|c|c|c|c|}
\hline Indices & WF-200 & WF-400 & WF-600 \\
\hline Quantity of Mesophilic Aerobic and Facultative A & $5 \times 10^{\wedge} 4$ & $5 \times 10^{\wedge} 4$ & $5 \times 10^{\wedge} 4$ \\
\hline \multicolumn{4}{|l|}{ Microorganisms (QMAFAnM), CFU / $0.1 \mathrm{~g}$} \\
\hline Mould, CFU / $0.1 \mathrm{~g}$, max. & 50 & 50 & 50 \\
\hline Pathogenic microorganisms (salmonella), in $25 \mathrm{~g}$ & abs./none & abs./none & abs./none \\
\hline Aflatoxins & abs./none & abs./none & abs./none \\
\hline CGB (Escherichia coli group bacteria) in $0.1 \mathrm{~g}$ & abs./none & abs./none & abs./none \\
\hline Pesticides and fungicides, $\mathrm{mg} / \mathrm{kg}$ & $<0.002$ & $<0.002$ & $<0.002$ \\
\hline
\end{tabular}

The results of the analysis of the chemical toxicants content are shown in Table 4.

Table 4. The content of heavy metals in the wheat fiber of the series "Vitacel", $\mathrm{mg} / \mathrm{kg}$

\begin{tabular}{lccc}
\hline \multicolumn{1}{c}{ Indices } & WF-200WF-400WF-600 \\
\hline Lead $(\mathrm{Pb})$ & 0.14 & 0.18 & 0.14 \\
Cadmium $(\mathrm{Cd})$ & $<0.01$ & 0.05 & 0.01 \\
Mercury (Hg) & $<0.01$ & 0.01 & 0.01 \\
Arsenic (As) & 0.01 & 0.1 & 0.01 \\
\hline
\end{tabular}

The results obtained positively characterize the prospects of the preparations for the manufacture of meat products. The evaluation of biological activity and safety of the wheat fiber preparations was carried out using the rapid bioassay (Table 5).

Table 5. Evaluation of the biological activity of the wheat fiber of the series "Vitacel"

\begin{tabular}{cccccc}
\hline Name of the & \multicolumn{5}{c}{ Index of the biological activity in dilution } \\
\cline { 2 - 6 } preparation (N/P) & $1: 100$ & $1: 1000$ & $1: 10000$ & $1: 100000$ & $1: 1000000$ \\
Control & 1.000 & 1.000 & 1.000 & 1.000 & 1.000 \\
"Vitacel" WF-200 & 1.073 & 1.054 & 1.000 & 1.000 & 1.000 \\
"Vitacel" WF-400 & 1.065 & 1.027 & 1.000 & 1.000 & 1.000 \\
"Vitacel" WF-600 & 1.031 & 1.021 & 1.000 & 1.000 & 1.000 \\
\hline
\end{tabular}

A free-living easily cultivated monocellular organism Paramecium caudatum was taken as a test object. The results confirmed the test samples to have biological activity, i.e. they are physiological for bioassay. So, the greatest stimulatory effect on the test objects was observed at a dilution of 1:1000.

To determine the use conditions of preparations of the series "Vitacel", their functional, technological, and commercial properties were studied. The summary and the average statistical data are given in Table 6.

Table 6. Evaluation of the biological activity of the wheat fiber of the series "Vitacel"

\begin{tabular}{|c|c|c|c|}
\hline Indices & WF-200 & WF-400 & WF-600 \\
\hline \multicolumn{4}{|l|}{ Physical abilities } \\
\hline$\overline{\mathrm{WBC}, \mathrm{H}_{2} \mathrm{O} / \mathrm{g}}$ & 8.6 & 11 & 4.9 \\
\hline Fat absorbability, fat/g & 6.9 & 12 & 3.7 \\
\hline \multicolumn{4}{|c|}{ Degree of water activity, Aw0.44 } \\
\hline Energy content, $\mathrm{kJ}$ & 0.4 & 0.4 & 0.4 \\
\hline Bulk density, $\mathrm{g} / \mathrm{dm} 3$ & \multicolumn{3}{|c|}{$85 \pm 15 \% 40 \pm 25 \% 210 \pm 15 \%$} \\
\hline \multicolumn{4}{|c|}{ Organoleptic characteristics } \\
\hline $\begin{array}{l}\text { Appearance } \\
\text { Flavour } \\
\text { Smell }\end{array}$ & \multicolumn{3}{|c|}{$\begin{array}{l}\text { white, powdered } \\
\text { neutral } \\
\text { neutral }\end{array}$} \\
\hline \multicolumn{4}{|c|}{ Analysis of the particle fineness (spray screen) } \\
\hline $\begin{array}{l}<200 \mu \mathrm{m}, \max . \\
<100 \mu \mathrm{m}, \max . \\
<32 \mu \mathrm{m}, \max .\end{array}$ & $\begin{array}{l}2 \% \\
20 \% \\
85 \% \\
\end{array}$ & & \\
\hline
\end{tabular}


The results showed that the preparations have a high water-binding and fat-retention capacities (FRC) and therefore there are great possibilities of their use in the meat systems that are water-protein-fat emulsions. The values of these parameters vary depending on the range of the preparations, and they can be arranged in ascending series: WF-600 $<\mathrm{WF}-200<\mathrm{WF}-400$.

The preparations are characterized by low water activity that confirms their high water binding capacity. The studies of the structural characteristics have shown that water binds with fiber chemically and capillary-osmotically. Neutral organoleptic properties and particle fineness also promote the preparations for the meat industry.

The measurements of the swelling properties of the preparations of the series "Vitacel" were repeated 10 times, lengthening the duration of the contact between the sample and the solvent. The results obtained are shown in Table 7.

Table 7. The swelling capacity of the wheat fiber of the series "Vitacel" WF-200

\begin{tabular}{llllll}
\hline $\begin{array}{l}\text { Process } \\
\text { time, } \tau, \mathrm{s} .\end{array}$ & $\begin{array}{l}\text { Swelling grade } \mathrm{i}, \\
\mathrm{sm} 3 / \mathrm{g}\end{array}$ & $\mathrm{X}=1 / \tau$ & $\mathrm{Y}=1 / \mathrm{i}$ & $\begin{array}{l}\text { Swelling rate, } \\
\mathrm{g} / \mathrm{s}, \mathrm{di} / \mathrm{d} \tau\end{array}$ & $\begin{array}{l}\mathrm{C} \text { is a constant of } \\
\text { the swelling rate }\end{array}$ \\
\hline 10 & 1.8 & 0.10 & 0.56 & 0.153 & 0.014 \\
20 & 3.4 & 0.05 & 0.31 & 0.120 & 0.013 \\
30 & 4.7 & 0.09 & 0.21 & 0.097 & 0.012 \\
40 & 5.6 & 0.025 & 0.18 & 0.079 & 0.013 \\
50 & 6.2 & 0.02 & 0.16 & 0.066 & 0.092 \\
60 & 6.5 & 0.01 & 0.15 & 0.056 & 0.0067 \\
70 & 6.6 & $0.8 \cdot 10^{-4}$ & 0.15 & $0.56 \cdot 10^{-3}$ & 0.0232 \\
\hline
\end{tabular}

The limiting degree of the swelling was determined by approximating the experimental data using the formula (1):

$$
i=i_{\max } \times\left(\frac{\alpha \tau}{1+\alpha \tau}\right)
$$

To do this, the equation (1) was lead to a linear form:

$$
\frac{1}{i}=\frac{1}{i_{\max }}+\frac{1}{\alpha \cdot i_{\max }} \times \frac{1}{\tau}
$$

and graphically determined $i_{\max }$ (Figure 3 ).

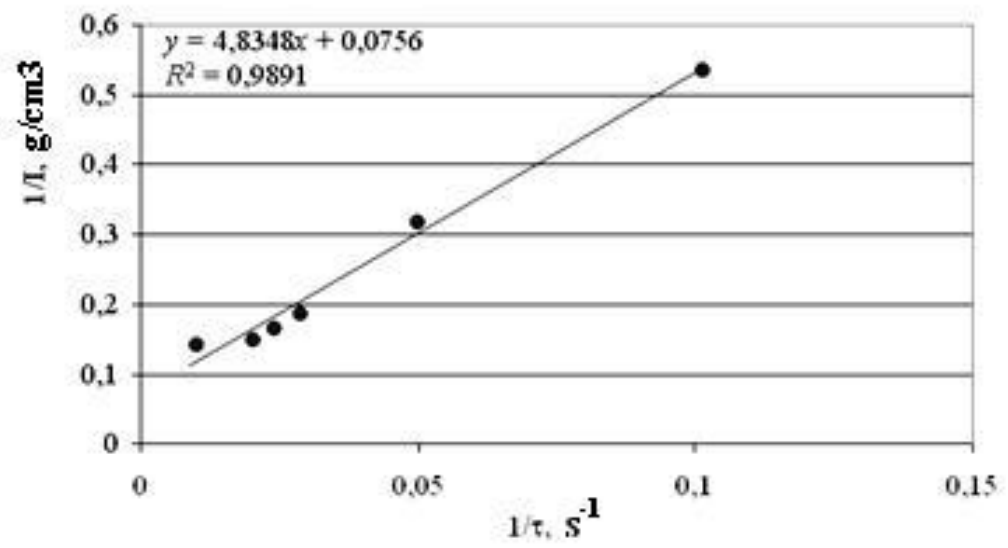

Figure 3. The limiting degree of the swelling of the preparation ("Vitacel" WF-200)

To study the adsorption of the wheat fiber "Vitacel", the experimental studies were carried out according to the schedule: each of seven dry conical flasks was charged with $1 \mathrm{~g}$ of a batch weight of wheat fiber "Vitacel" WF-200. Each flask was poured $25 \mathrm{~cm} 3$ of acetic acid solutions of predetermined concentrations (in the range of 
0.01-0.5 mol/dm3). The adsorption was performed vortexing for $20 \mathrm{~min}$. After the adsorption, the solutions were filtered through some folded paper filters, and the initial and equilibrium concentrations of the acid were measured. For this purpose, a test sample of $10 \mathrm{~cm} 3$ was taken from each starting solution and from the filtrate, and each sample was titrated with sodium hydroxide solution with phenolphthalein as an indicator. The results obtained are shown in Table 8.

Table 8. The specific adsorption of the wheat fiber of the series "Vitacel" WF-200

\begin{tabular}{ccccc}
\hline $\begin{array}{c}\text { Starting } \mathrm{C}_{0}, \\
\mathrm{~mol} / \mathrm{dm} 3\end{array}$ & $\begin{array}{c}\text { Final C, } \\
\mathrm{mol} / \mathrm{dm} 3, \mathrm{x} 10^{\wedge}-3\end{array}$ & $\begin{array}{c}\text { Adsorption A, } \\
\mathrm{mol} / \mathrm{g}, \mathrm{x} 10^{\wedge}-6\end{array}$ & $\begin{array}{c}1 / \mathrm{A}, \\
\mathrm{g} / \mathrm{mol}, \mathrm{x} 10^{\wedge} 3\end{array}$ & $\begin{array}{c}1 / \mathrm{C}, \\
\mathrm{x} 10^{\wedge} 3\end{array}$ \\
\hline 0.0200 & 9.0 & 55 & 18.0 & 0.11 \\
0.0132 & 11.2 & 80 & 12.5 & 0.08 \\
0.0226 & 20.8 & 90 & 11.0 & 0.04 \\
0.0500 & 51.0 & 200 & 5.0 & 0.02 \\
0.1050 & 100.0 & 250 & 4.0 & 0.01 \\
\hline
\end{tabular}

The study confirmed that the sorption properties depend on the contact duration and the solution volume. In the course of this work, the Amax adsorption capacity of the wheat fiber "Vitacel" was identified, the specific surface area $S s p=50.1165 \mathrm{~m} 2 / \mathrm{g}$ was found. It underlines the usefulness and the prospect of the preparations as adsorbents of different substances. Their good sorption capacity opens up the prospect and practicability of their application in the food technology as a functional ingredient and stabilizer of the food systems.

When determining the water-retention capacity, a series of 10 suspensions at the intervals of $2.0 \mathrm{~g}$ of water per 1 $\mathrm{g}$ of the preparation was prepared from the initial slurry, for example, for the traditional concentrate 1:4; 1:6;1:8 and so on. The suspensions were mixed thoroughly to the homogenous consistency, transferred to the centrifuge tubes of $10 \mathrm{ml}$ (about $10 \mathrm{~g}$ ), placed in a thermostat at a temperature of $74-76^{\circ} \mathrm{C}$, and held for 15 minutes. The tubes were then water cooled to room temperature and centrifuged at $2000 \mathrm{r} / \mathrm{min}$ for $10 \mathrm{~min}$ (with the maximum possible $8000 \mathrm{r} / \mathrm{min}$ ). The maximum amount of the added water, with no separation of the aqueous phase to be observed during the testing, on conversion to $1 \mathrm{~g}$ of the preparation, was taken as a value of the CWS. The MAS expressed in grams of water per $1 \mathrm{~g}$ of the preparation. The graphical interpretation of the data is presented in Figures 4-5.

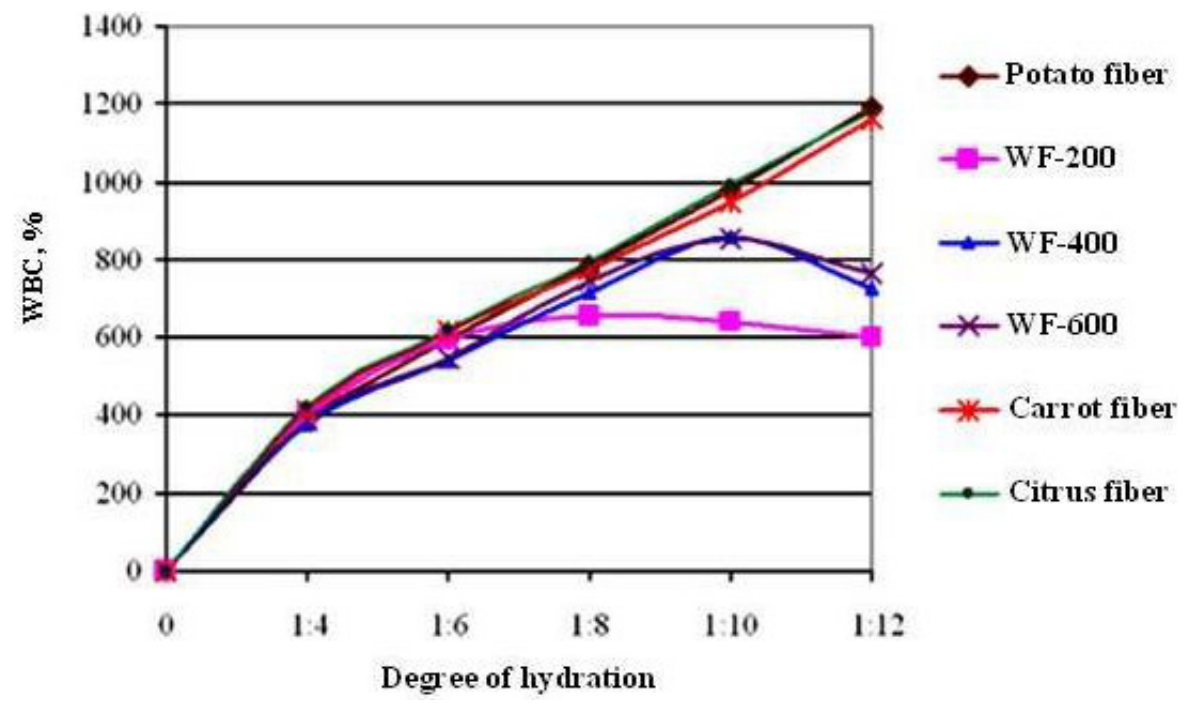

Figure 4. Changes in WBC of the preparation of the series "Vitacel" 


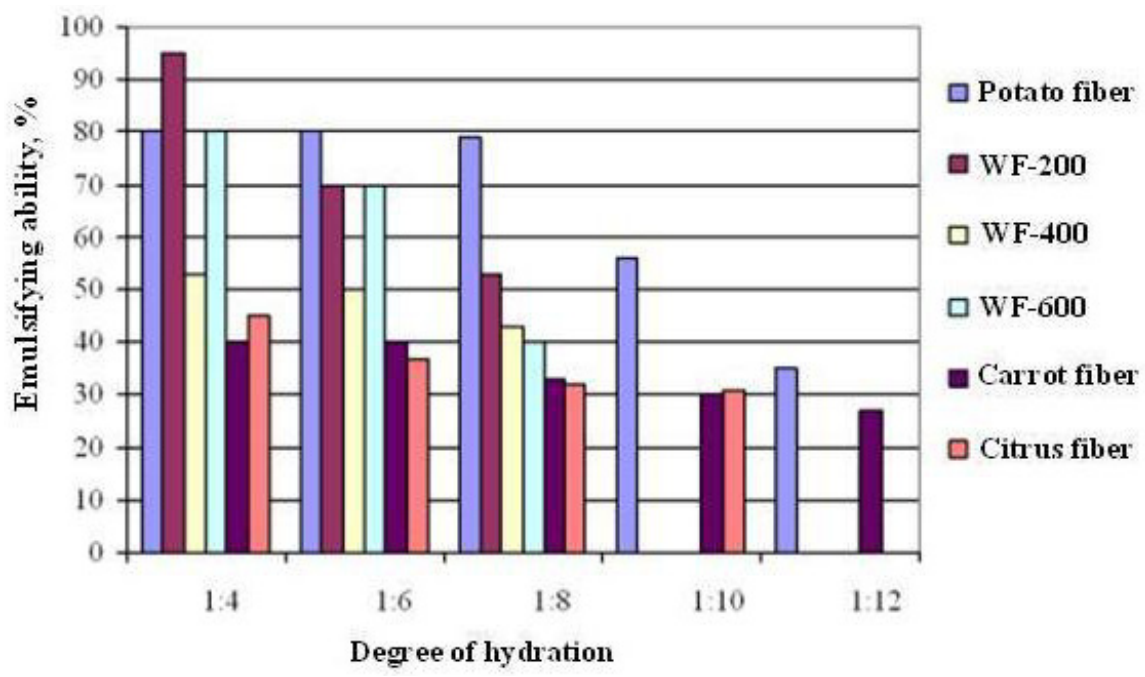

Figure 5. Changes in emulsifying ability (EA) of the preparation of the series "Vitacel"

The comparative data showed that the water binding and the water retention capacities of the wheat fiber of the series "Vitacel" WF-200-600 are 1:10; WF-400 are 1:8. For the potato, carrot, and citrus fibers, the best results are achieved at a ratio of 1:10-12 or more. The analysis of the experimental data to determine the emulsifying ability of different fibers showed that higher values are obtained at a ratio of: 1:8:8 - potato fiber; 1:4:4 WF-200-400-600, citrus fiber; 1:6:6 - carrot fiber.

The results of the study of the functional and technological properties of the model sausage fillings using the preparations of the series "Vitacel" WF-200 instead of the adequate share of the basic raw materials are shown in Table 9.

Table 9. Functional and technological properties of the model sausage fillings (with "Vitacel" WF-200)

\begin{tabular}{llllll}
\hline Mass fraction of the additive & WBC, \% & WHC, \% & FRC, \% & EA, \% & Emulsion stability, \% \\
\hline 0 & 51.9 & 48.3 & 55.3 & 49.2 & 53.1 \\
2 & 56.8 & 50.4 & 60.0 & 52.2 & 56.8 \\
4 & 70.6 & 64.7 & 70.3 & 60.1 & 64.9 \\
6 & 71.5 & 66.1 & 70.5 & 60.7 & 65.7 \\
8 & 69.3 & 63.9 & 67.6 & 58.5 & 63.8 \\
10 & 67.9 & 61.8 & 66.0 & 56.3 & 61.7 \\
\hline
\end{tabular}

The forcemeat with different percentage of lean pork, beef of premium grade, and "Vitacel" was used as a model sausage filling. The analysis of the experimental data shows that the maximum values are achieved when adding 4-6\% of "Vitacel" to the stuffing instead of the basic raw material and make 70.6-71.5\%, 64.7-66.1\%, respectively. When adding "Vitacel" more than 4-6\%, the values of the WBC and the WHC are somewhat below, although they are still at a fairly high level. When adding fiber less than $4-6 \%$, the values of the WBC and the WHC also reduced. The FRC of the model sausage fillings increases when adding the fiber instead of the basic raw material and is $70.3-70.5 \%$.

The effect of the wheat fiber "Vitacel" on the color-forming ability of nitrite in the forcemeat systems is of great interest. To determine the dependence of the color of the model sausages on the adding proportion of the preparation of the series "Vitacel" WF-200, some model sausage fillings containing 50\% of premium grade beef and $50 \%$ of semifat pork meat were developed. Sodium nitrite was added at the stage of chopping at a concentration of $7.5 \mathrm{mg} \%$ to the weight of the raw material unsalted. The results are shown in the colorimetric system CIE L*a*b* and XYZ (Table 10). 
Table 10. The color characteristics of the sausage samples with the wheat fiber "Vitacel"

\begin{tabular}{|c|c|c|c|c|c|c|c|c|}
\hline \multirow{3}{*}{\multicolumn{2}{|c|}{$\mathrm{N} / \mathrm{P}$ Ratio of the addition $\%$}} & \multicolumn{7}{|c|}{ Color characteristics } \\
\hline & & \multirow{2}{*}{\multicolumn{2}{|c|}{$\begin{array}{l}\text { Color coordinates } \\
\end{array}$}} & \multirow{2}{*}{ ldev } & \multirow{2}{*}{$\mathrm{L}^{*}$} & \multirow{2}{*}{$\mathrm{a}^{*}$} & \multirow[t]{2}{*}{$\mathrm{b}^{*}$} & \multirow[t]{2}{*}{$\mathrm{S}$} \\
\hline & & & $\mathrm{Y}$ & & & & & \\
\hline 1 & 0 & 0.3466 & 0.31152 & 0.00000 & 45.58 & 18.07 & 8.14 & 19.81 \\
\hline 2 & 2 & 0.3462 & 0.31172 & 0.00044 & 46.95 & 18.11 & 8.26 & 19.90 \\
\hline 3 & 4 & 0.3437 & 0.31214 & 0.00294 & 47.13 & 17.75 & 8.37 & 19.62 \\
\hline 4 & 6 & 0.3424 & 0.31221 & 0.00425 & 47.24 & 17.69 & 8.63 & 19.68 \\
\hline 5 & 8 & 0.3409 & 0.31267 & 0.00581 & 48.27 & 17.17 & 8.71 & 19.25 \\
\hline 6 & 10 & 0.3401 & 0.31293 & 0.00665 & 49.12 & 17.12 & 8.65 & 19.35 \\
\hline
\end{tabular}

Figure 6 shows that the complete color distinctiveness $\Delta \mathrm{E}$ value is 3.65 with $10 \%$ share of application. This is an acceptable level of deviation in color. Therefore, the application of "Vitacel" at a concentration of $4-6 \%$ does not cause significant changes in color, and it does not require correction.

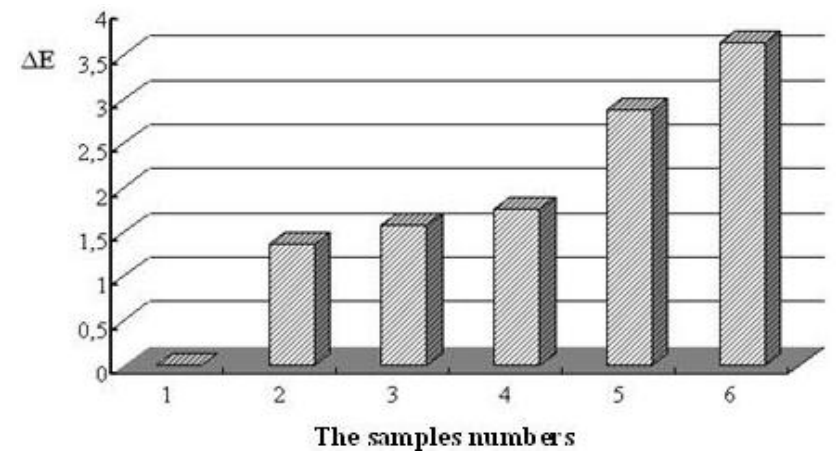

Figure 6. Full color differences $\Delta \mathrm{E}$ of the model samples of sausages with wheat fiber "Vitacel"

The smell stability assessment of the model sausage fillings with the fiber "Vitacel" was conducted on the "electronic nose", consisting of a detection cell, piezoresonant sensors, a frequency indicator, and a compressor (Korenman \& Kuchmenko, 2002). The experimental studies were conducted under the following conditions: the sorbent - Triton X-100, $\mathrm{m}$ (of the film) $=14$. The samples were subjected to the analysis: 1 - model sausage filling (50\% of beef, $50 \%$ of pork); 2 - "Vitacel" WF-200 (100\%); 3 - model sausage filling + 2\% "Vitacel" WF-200 instead of the basic raw material; 4 - model stuffing $+4 \%$ "Vitacel» WF-200 instead of the basic raw material; 5 - model stuffing $+6 \%$ "Vitacel» WF-200 instead of the basic raw material; 6 - model sausage filling + 8\% "Vitacel»WF-200 instead of the basic raw material; 7 - model stuffing + 10\% "Vitacel» WF-200 instead of the basic raw material. The results of the research helped to build a diagram of the model stuffing flavor depending on the storage duration (Figure 7).

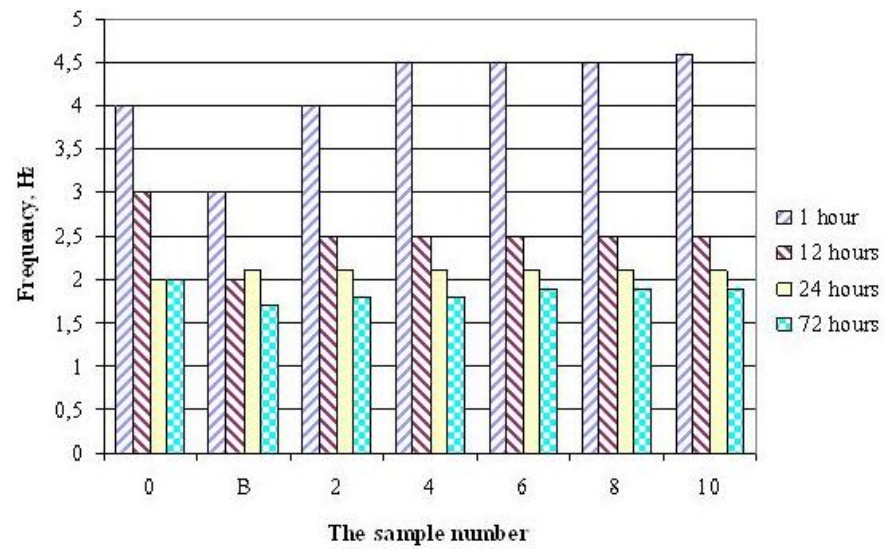

Figure 7. The change of the aromatics sorption of the model forcemeats depending on the storage duration: 0 model stuffing; B - "Vitacel" (100\%); 2 - model sausage filling + 2\% "Vitacel"; 4 - model stuffing + 4\% "Vitacel"; 6 - model stuffing $+6 \%$ "Vitacel" instead of the basic raw material; 8 - model sausage filling $+8 \%$ "Vitacel"; 10 - model stuffing + 10\% "Vitacel" 
Thus, "Vitacel" at a concentration of $2-10 \%$ in the sausage filling systems not to affect the flavor of the products. The products have higher rates than the actual fiber and the model stuffing without fiber. The application of the wheat fiber "Vitacel»WF-200 as part of the meat product formulations can preserve fragrance for long periods of storage.

For more complete characteristics of the nutritional and biological value of the sausages (Table 11), the amino-acid score, the utility coefficient, the comparable redundancy ratio, the difference coefficient of the amino acids score (DCAAS) were defined.

Table 11. Biological value (BV) of the cooked meat products developed

\begin{tabular}{lcccc}
\hline The name of the sample & DCAAS, \% & BV, \% & $\begin{array}{l}\text { Utility coefficient of the } \\
\text { amino-acid composition }\end{array}$ & $\begin{array}{c}\text { "Comparable } \\
\text { redundancy" ratio }\end{array}$ \\
\hline $\begin{array}{l}\text { Cooked sausage } \\
\text { «Lyubimaya» }\end{array}$ & 20.6 & 79.4 & 0.970 & -35.35 \\
$\begin{array}{l}\text { Small semi-smoked } \\
\text { sausages «Stolichniye» }\end{array}$ & 19.9 & 80.1 & 0.804 & -35.36 \\
\hline
\end{tabular}

The studies to determine the biological activity and safety of the sausages were conducted using a rapid bioassay. A free-living easily cultivated monocellular organism Paramecium caudatum was taken as a test object. The rapid bioassay is quite sensitive to the active substances contained in the test objects and reflects their relationship to the viability of the organism. The rate of flow of the vital processes in the test organism depends on the impact of the quality and the quantity of the edible substrate. The evaluation of the biological activity and safety of the developed sausages are presented in Table 12.

Table 12. The evaluation of the biological activity and safety of the sausages

\begin{tabular}{lccccc}
\hline \multirow{2}{*}{ The test sample } & \multicolumn{4}{c}{ Index of the biological activity of the objects in dilution } \\
\cline { 2 - 5 } & $1: 100$ & $1: 1000$ & $1: 10000$ & $1: 100000$ & $1: 1000000$ \\
\hline The control sample & 1.000 & 1.000 & 1.000 & 1.000 & 1.000 \\
Cooked sausage «Lyubimaya» & 1.180 & 1.060 & 1.000 & 1.000 & 1.000 \\
Small semi-smoked sausages «Stolichniye» & 1.070 & 1.030 & 1.000 & 1.000 & 1.000 \\
\hline
\end{tabular}

The test samples have biological activity, i.e. are physiological for the bioassay. The greatest stimulatory effect on the test objects were observed at a dilution of 1: 10000 .

\section{Conclusion}

Thus, based on the research results, we can conclude that the fiber of the series "Vitacel" has a number of positive functional and technological properties that allows recommending it for all kinds of meat, fish, and confectionery products. The preparations not being food supplements are of great interest not only in terms of technology, but also necessary in the implementation of the Scientific Concepts of Functional Foods in Europe.

\section{Acknowledgements}

The authors are grateful to the Russian Science Foundation for the financial support in the implementation of this research according to the scientific project \# 15-16-10000, NIIMMP.

\section{References}

Antipova, L. V., Glotova, I. A., \& Rogov, I. A. (2001). Research methods of meat and meat products. Moscow, Russia: Kolos, p.376.

Antipova, L. V., Glotova, I. L., Titov, S. A., \& Panov, V. P. (2002). Control the chromaticity of meat and meat products based on the methods of spectrophotometry. Myasnaya industriya, 8, 48-50.

Bchir, B., Rabetafika, H. N., Paquot, M., \& Blecker, C. (2014). Effect of Pear, Apple and Date Fibres from Cooked Fruit By-products on Dough Performance and Bread Quality. Food and Bioprocess Technology, 7(4), 1114-1127.

Cho, S., \& Almeida, N. (2012). Dietary Fiber and Health. Boca Raton, USA: CRC Press, p. 557.

Cui, S. W., Nie, S., \& Roberts, K. T. (2011). Functional properties of dietary fibre. Biotechnology, 4, 517-525. 
Dahm, C. C., Keogh, R. H., Greenwood, D. C., Fentiman, I. S., Shipley, M. J., Brunner, E. J., .. Key, T. J. (2010). Dietary fiber and colorectal cancer risk: a nested case-control study using food diaries. Journal of the National Cancer Institute, 102(9), 614-626.

Dhingra, D., Michael, M., Rajput, H., \& Patil, R. T. (2012). Dietary fibre in foods: a review. Journal of Food Science and Technology, 49, 255-266.

Dülger, D., \& Şahan, Y. (2011). Diyet Lifin Özellikleri ve Sağllk Üzerindeki Etkileri. U.Ü. ZiraatFakültesi Dergisi, 25(2), 147-157.

Elleuch, M., Bedigian, D., Roiseux, O., Besbes, S., Blecker, C., \& Attia, H. (2011). Dietary fibre and fibre-rich by-products of food processing: Characterisation, technological functionality and commercial applications: A review. Food Chemistry, 124(2), 411-421.

Eshak, E. S., Iso, H., Date, C., Kikuchi, S., Watanabe, Y., Wada, Y., ... JACC Study Group. (2010). Dietary fiber intake is associated with reduced risk of mortality from cardiovascular disease among Japanese Men and Women. Journal of Nutrition, 140, 1445-1453.

European Food Safety Authority. (2010). Scientific opinion on dietary reference values for carbohydrates and dietary fibre. EFSA Journal, 8(3), 1462.

Grossi, A., Søltoft-Jensen, J., Knudsen, J. C., Christensen, M., \& Orlien, V. (2011). Synergistic cooperation of high pressure and carrot dietary fibre on texture and colour of pork sausages. Meat Science, 89, 195-201.

Grau, R., \& Hamm, R. (1957). Über das Wasserbindungsvermögen des Saugetiermuskels II. Mitt. Über die Bestimmung der Wasserbindung des Muskels. Zeitschrift für Lebensmittel-Untersuchung und Forschung, $105,446-460$.

Hong, Y., Zi-jun, W., Jian, X., Ying-jie, D., \& Fang, M. (2012). Development of the dietary fiber functional food and studies on its toxicological and physiologic properties. Food and Chemical Toxicology, 50, 3367-3374.

International Organization for Standardization (ISO) (2010). Sensory analysis general guidance for the design of test rooms. International Standard 8589. Ref. no ISO 8589:2010 (E). Genevè: ISO.

Jones, J. M. (2013). Dietary fiber future directions: integrating new definitions and findings to inform nutrition research and communication. Advances in nutrition (Bethesda, Md.), 4(1), 8-15.

Kamaljit, K., Amarjeet, K., \& Tarvinder, P. S. (2011). Analysis of ingredients, functionality, formulation optimalization and shelf life evaluation of high fiber bread. American Journal of Food Technology, 6, 306-313.

Kendall, C. W. C., Esfahani, A., \& Jenkins, D. J. A. (2010). The link between dietary fibre and human health. Food Hydrocolloids, 24, 42-48.

Kohajdová, Z., Karovičová, J., \& Jurasová, M. (2013). Influence of grapefruit dietary fibre rich powder on the rheological characteristics of wheat flour dough and on biscuit quality. Acta Alimentaria, 42, 91-101.

Korenman, Ia. I., \& Kuchmenko, T. A. (2002). Approaches to the analysis of food products. development of mass-sensitive sensors. Russian chemical journal, 46(4), 34-42.

Leão, D. P., Melo, J. C. S., Franca, A. S., \& Oliveira L. S. (2013). Comparative Evaluation of Agricultural Residues in the Production of Dietary Fibers. Proceedings of 2nd International Conference on Nutrition and Food Sciences. Singapore: IACSIT Press. IPCBEE, 53(7), 34-38.

McGill, C. R., Fulgoni, V. L. III, \& Devareddy, L. (2015). Ten-year trends in fiber and whole grain intakes and food sources for the United States population: National Health and Nutrition Examination Survey 2001-2010. Nutrients, 7(2), 1119-1130.

Mehta, N., Ahlawat, S. S., Sharma, D. P., \& Dabur, R. S. (2015). Novel trends in development of dietary fiber rich meat products - a critical review. Journal of Food Science and Technology, 52(2), 633-647.

O'Shea, N., Arendt, E. K., \& Gallagher, E. (2012). Dietary fibre and phytochemical characteristics of fruit and vegetable by-products and their recent applications as novel ingredients in food products. Innovative Food Science and Emerging Technologies, 16, 1-10.

Pogozheva, A. V., Kodentsova, V. M., Vrzhesinskaya, O. A., Derbeneva, S. A., Beketova, N. A., Pereverzeva, O. G., \& Kosheleva, O. V. (2010). Dietary fiber influence on vitamins assimilation in patients suffering from cardiovascular diseases and adiposity. Voprosy pitania, 79(1), 34-39.

Ramirez-Santiago, C., Ramos-Solis, L., Lobato-Calleros, C., Peña-Valdivia, C., Vernon-Carter, E. J., \& 
Alvarez-Ramírez, J. (2010). Enrichment of stirred yogurt with soluble dietary fiber from Pachyrhizus erosus L. Urban: Effect on syneresis, microstructure and rheological properties. Journal of Food Engineering, 101, 229-235.

Sánchez-Zapata, E., Díaz-Vela, J., Pérez-Chabela, M. L., Pérez-Alvarez, J. A., \& Fernández-López, J. (2013). Evaluation of the Effect of Tiger Nut Fibre as a Carrier of Unsaturated Fatty Acids Rich Oil on the Quality of Dry-Cured Sausages. Food and Bioprocess Technology, 6(5), 1181-1190.

Stromberg, A. G., \& Semchenko, D. P. (2001). Physical chemistry. Moscow, Russia: Vysshaya shkola, p.527.

Tuominen, R., \& Honkavaara, M. (1982). Effect of electrically stimulated meat on processing properties of cooked sausage. In Proceedings 28th European Meeting of Meat Research Workers. Madrid, Spain, 4.18.

Van Der Kamp, J. W., Jones, J., McCleary, B., \& Topping D. J. (2010). Dietary fibre: New frontiers for food and health. Wageningen, The Netherlands: Wageningen Academic Publishers, p.586.

Viuda-Martos, M., López-Marcos, M., Fernández-López, J., Sendra, E., López-Vargas, J. H., \& Pérez-Alvarez, J. A. (2010). Role of fiber in cardiovascular diseases. Comprehensive Reviews in Food Science and Food Safety, 9, 240-258.

Yangilar, F. (2013). The Application of Dietary Fibre in Food Industry: Structural Features, Effects on Health and Definition, Obtaining and Analysis of Dietary Fibre: A Review. Journal of Food and Nutrition Research, $1(3), 13-23$.

\section{Copyrights}

Copyright for this article is retained by the author(s), with first publication rights granted to the journal.

This is an open-access article distributed under the terms and conditions of the Creative Commons Attribution license (http://creativecommons.org/licenses/by/3.0/). 